\title{
PEMBERDAYAAN MASYARAKAT PEMANCINGAN RAMA MELALUI PELATIHAN PENGOLAHAN KERUPUK IKAN LELE GUNA MENINGKATKAN PEREKONOMIAN MASYARAKAT KELURAHAN GRAHA INDAH KOTA BALIKPAPAN
}

\author{
Budiani F. Endrawati ${ }^{1}$, Chandra S. Rahendaputri²), Ismi Khairunnissa ${ }^{2)}$ \\ 1)Teknik Industri, Jurusan Teknologi Industri dan Proses, Institut Teknologi Kalimantan, Balikpapan, \\ Kalimantan Timur, Indonesia \\ ${ }^{2)}$ Teknik Lingkungan, Jurusan IImu Kebumian dan Lingkungan, Institut Teknologi Kalimantan, Balikpapan, \\ Kalimantan Timur, Indonesia \\ Corresponding author : Chandra S. Rahendaputri \\ E-mail : chandra.suryani03@lecturer.itk.ac.id
}

\section{Diterima 22 Oktober 2021, Direvisi 03 November 2021, Disetujui 03 November 2021}

\begin{abstract}
ABSTRAK
Program Mahasiswa Mengabdi Desa dilakukan di Kelurahan Graha Indah, Kecamatan Balikpapan Utara, tepatnya pada RT. 5 dan RT. 60. Dengan adanya Pemancingan Rama, tim pengabdian masyarakat melihat adanya potensi UMKM dengan membuat kerupuk ikan lele.Oleh karena itu, tim mengadakan pelatihan pengolahan kerupuk ikan lele guna meningkatkan perekonomian masyarakat mitra ini. Metode yang digunakan dalam pelaksanaan pengabdian masyarakat ini adalah menggunakan metode pelatihan secara daring berbentuk webinar, dan pendampingan langsung dalam pelatihan pembuatan kerupuk ikan lele. Selain itu, pendampingan dilakukan dalam penjualan kerupuk ikan lele. Untuk mengetahui kebermanfaatan webinar dan luaran webinar, dilakukan survei. Hasil survei menunjukkan bahwa $94.4 \%$ peserta dari total 18 peserta menyatakan kegiatan ini bermanfaat. Namun, kurang dari setengah peserta yang akan menjadikan ikan lele sebagai bisnis, yakni sebesar $44.4 \%$ saja. Hal ini disebabkan beberapa peserta merasa masih belum berhasil membuat kerupuk ikan lele yang layak jual. Lainnya merasa belum memiliki kemampuan dalam promosi dan penjualan, sehingga hanya tertarik untuk belajar saja. Dari kegiatan ini dihasilkan 49 kemasan kerupuk ikan lele, dengan 44 kemasan berhasil dijual.
\end{abstract}

Kata kunci: Ikan lele; kerupuk; pengabdian masyarakat; UMKM

\begin{abstract}
The Community Service was held in Kelurahan Graha Indah, North Balikpapan District, precisely at RT. 5 and RT. 60. With Rama Fishing, the community service team saw the potential of MSMEs by making catfish crackers. The method used in the implementation of this community service is using online training methods in the form of webinars, and direct assistance offline in training on making catfish crackers. In addition, assistance is provided in the sale of catfish crackers. To find out the usefulness of the webinar and the outcome of the webinar, a survey was conducted. The survey results showed that $94.4 \%$ of participants from a total of 18 participants stated that this activity was useful. However, less than half of the participants will turn catfish crackers into their business, which is merely $44.4 \%$. This was because some participants felt they had not succeeded in making catfish crackers that were worth selling. Others feel that they do not have the ability to promote and sell, so they are only interested in learning. From this activity, 49 packages of catfish crackers were produced, of which 44 were successfully sold.
\end{abstract}

Keywords: catfish; crackers; community service; MSMEs

\section{PENDAHULUAN}

Kelurahan Graha Indah, Kota Balikpapan, merupakan salah satu kelurahan yang berada di kecamatan Balikpapan Utara yang terbentuk pada tahun 2012 yang merupakan pemekaran dari kelurahan Batu Ampar. Kepadatan penduduk yang berada di wilayah kelurahan Graha Indah menurut Kecamatan Balikpapan Utara dalam angka tahun 2019 bahwa penduduk laki laki pada kelurahan Graha Indah sebanyak 18.176 jiwa, lalu untuk jumlah penduduk perempuan yakni adalah 16.857 jiwa dengan total keseluruhan penduduk yang ada di kelurahan Graha Indah yakni sebanyak 35.033 jiwa.

Masyarakat di Kelurahan Graha Indah setiap harinya melakukan berbagai jenis kegiatan dan aktivitas untuk mengatasi 
permasalahan ekonomi seperti pergi bekerja, berjualan makanan, ikan, ayam, membuka toko, membuka tempat hiburan, membuka jasa cuci motor, dan lainnya. Berdasarkan data kependudukan yang berasal dari Kecamatan Balikpapan Utara dalam angka, 2019 menjelaskan bahwa pada kawasan di Kelurahan Graha Indah memiliki beberapa jenis pekerjaan yang berbeda. Beberapa lapangan pekerjaan yang ada di kelurahan Graha Indah yakni adalah pedagang sebesar 357 jiwa, petani sebesar 334 jiwa, buruh sebesar 1411 jiwa, dan lainnya (Balikpapan, 2019).

Di Kelurahan ini juga terdapat tempat pemancingan ikan, yang dapat menjadi tempat untuk hiburan, transaksi jual beli ikan, tempat memancing, dan dapat menjadi tempat tujuan wisata bagi masyarakat Balikpapan maupun dari luar kota sekalipun. Pada wilayah Kelurahan Graha Indah ini memiliki dua buah wisata pemancingan, salah satunya adalah Pemancingan Rama. Namun, di masa pandemi ini, pengunjung Pemancingan Rarma semakin menurun, sehingga menurunkan pemasukan dari penduduk sekitar. Pariwisata ini menurut data yang ditelaah oleh P2E LIPI, menurunkan penjualan UMKM mikro yang menjual makanan dan minuman sebesar $27 \%$, dan $1.77 \%$ pada usaha kecil makanan dan minuman (Bahtiar \& Saragih, 2020). Di penelitian lain, didapatkan bahwa industri yang terdampak COVID 19 meliputi manufaktur, transportasi dan pariwisata dimana yang berhasil bertahan hanya industri yang berkaitan dengan kebutuhan dasar(Rosita, 2020).

Untuk menjawab permasalahan mitra seperti yang telah dijelaskan sebelumnya, dan melihat potensi UMKM pendukung dari adanya kolam pemancingan Rama, tim pengabdian masyarakat Institut Teknologi Kalimantan dalam Program Mahasiswa Mengabdi Desa, melakukan kegiatan pengabdian masyarakat dengan judul "Pemberdayaan Masyarakat Pemancingan Rama melalui Pelatihan Pengolahan Kerupuk Ikan Lele guna Meningkatkan Perekonomian Masyarakat Kelurahan Graha Indah". Kegiatan ini diharapkan dapat meningkatkan perekonomian masyarakat Kelurahan Graha Indah terutama ibu- ibu di RT 05 dan RT 60 Kelurahan Graha Indah, Kota Balikpapan, dengan melihat adanya potensi tempat pemancingan ini.

\section{METODE}

Kegiatan ini dilaksanakan selama 5 bulan dalam satu semester dan dilaksanakan secara online. Karena pada saat itu kasus COVID sedang meningkat di daerah tersebut, pihak berwenang dikawasan tersebut sepakat untuk melaksanakan kegiatan ini secara online.
Ada beberapa tahap yang dilakukan dalam kegiatan ini yaitu perkenalan via zoom, pembelian dan pemberian bahan ke lokasi mitra, sosialisasi mengenai cara pembuatan kerupuk lele via zoom, monitoring pembuatan kerupuk ikan lele, dan yang terakhir adalah penjualan kerupuk ikan lele.

\section{Perkenalan Via Zoom}

Tim pengabdian masyarakat mengadakan sosialisasi pada tanggal 20 Maret 2021 melalui zoom, dimana masyarakat, baik dari RT 05 dan RT 60, diberi arahan untuk persiapan webinar yang akan datang dengan mengenalkan konsep kegiatan, mengenalkan produk beserta resep yang akan menjadi bahan pelatihan nantinya, dan diberi materi sociopreneur untuk meningkatkan wawasan masyarakat terhadap penjualan produk hasil pelatihan sehingga mendapat gambaran dan bekal untuk kedepannya. Untuk memudahkan koordinasi dengan peserta dan tim, dibuat grup Whatsapp yang nantinya dari peserta yang bersedia mengikuti kegiatan kegiatan akan didaftar dan diarahkan untuk masuk grup. Serta outputnya dari sosialisasi ini adalah masyarakat bisa mendapatkan gambaran untuk pelaksanaan webinar yang akan ada pelatihan selama kegiatan berlangsung.

Pada tahapan ini, panitia melakukan koordinasi dengan pemilik mitra Pemancingan Rama, Ketua RT. 05 dan Ketua RT. 60 dengan memberikan informasi mengenai peraturan teknis webinar serta link zoom meeting. Selain itu, informasi ini juga disebarkan oleh tim Humas Program Mahasiswa Mengabdi Desa kepada warga mitra RT. 05 dan Ketua RT. 60 via grup Whatsapp. Selain itu, gladi bersih juga dilakukan agar webinar sosialisasi pelatihan dapat berjalan lancar. Kegiatan webinar ini dipandu oleh seorang moderator dari tim Program Mahasiswa Mengabdi Desa. Pada gladi bersih ini, dibahas juga terkait kendala perangkat/jaringan yang mungkin dihadapi saat kegiatan webinar berlangsung dan bagaimana cara mengatasi permasalahan tersebut.

\section{Pembelian dan pemberian bahan ke lokasi mitra}

Bahan pembuatan produk Kerupuk Ikan Lele disediakan oleh tim. Oleh karena itu, dilakukan belanja bahan seperti minyak, garam, tepung kanji, gula, ikan lele, plastik standing pouch, plastik lontong, telur, plastik setengah kilo, dan plastik hitam. Semua bahan kemudian dibagi - bagi dalam beberapa paket, untuk memudahkan distribusi ke tiap peserta. Untuk peserta KKN di RT 05 ada 10 orang dan untuk RT 60 ada 8 orang. Untuk peserta yang tidak dapat langsung mengambil bahannya, akan 
diambil langsung oleh masing-masing ketua RT kemudian para peserta akan mengambilnya.

\section{Sosialisasi cara pembuatan kerupuk ikan lele melalui webinar}

Terdapat dua rangkaian webinar yaitu webinar pelatihan dengan membahas tata cara pembuatan kerupuk ikan lele dan webinar kewirausahaan dengan membahas seputar ilmu kewirausahaan.

Untuk webinar pertama dilaksanakan menggunakan via zoom, dihadiri oleh Ketua RT 05 dan peserta pelatihan. Dalam webinar ini tim mengajarkan kepada peserta tentang pembuatan kerupuk ikan lele dari mulai membersihkan ikan lele, membuat adonan kerupuk hingga penjemuran sebelum kerupuk bisa dimasak. Untuk memudahkan peserta, tim juga membuat video pembelajaran yang diupload melalui laman youtube, dan dapat diputar kembali di rumah masing - masing oleh peserta. Pemilihan ikan lele yaitu karena ikan lele memiliki kandungan protein tinggi yang baik untuk kesehatan (Listyarini et al., 2018). Selain itu, kandungan asam lemak tak jenuh pada lele juga memberikan kebermanfaatan untuk jantung(Asriani et al., 2019).

Setelah dipaparkan mengenai resep dan juga cara pembuatan saat webinar, serta telah mendapatkan bahan-bahan yang diperlukan, peserta melalukan praktik secara mandiri dirumah masing-masing. Peserta kemudian diarahkan untuk terus menginformasikan progresnya kepada penanggung jawab masing-masing.

Pelaksanaan webinar kedua yaitu webinar kewirausahaan yang membahas ilmu kewirausahaan, cara memasarkan produk, serta motivasi untuk terus semangat dalam menjalankan bisnis. Hasil rekaman webinar ini juga diberikan ke peserta melalui whatsapp group.

\section{Monitoring pembuatan kerupuk ikan lele}

Kegiatan monitoring ini dilakukan dengan cara membagi peserta di dalam kelompok - kelompok dan menempatkan seorang penanggung jawab di setiap kelompoknya. Di dalam kelompok ini, peserta juga diarahakan untuk mendokumentasikan pengolahan kerupuk dari tahap awal hingga tahap penjemuran, penggorengan, pengemasan, hingga tahap promosi.

\section{Penjualan kerupuk ikan lele}

Setelah melakukan kegiatan webinar dan monitoring secara online dengan mengkonfirmasikan di Whatsapp Group atau personal kontak ke penanggung jawab guna melihat perkembangan produksinya dalam mengolah kerupuk ikan lele, ikan lele tersebut kemudian dijual oleh para peserta. Promosi dan penjualan diatur sendiri oleh peserta, baik dipromosikan dengan teman arisan, dijual di warung sendiri, atau secara online via Whatsapp dan aplikasi lainnya.

\section{HASIL DAN PEMBAHASAN \\ Pelaksanaan Webinar}

Webinar telah dilaksanakan sebanyak 5 kali. Webinar ini mencakup sosialisasi kegiatan, pelatihan pembuatan kerupuk, diskusi setelah pelatihan pembuatan kerupuk, webinar kewirausahaan dan penutupan (gambar 1).

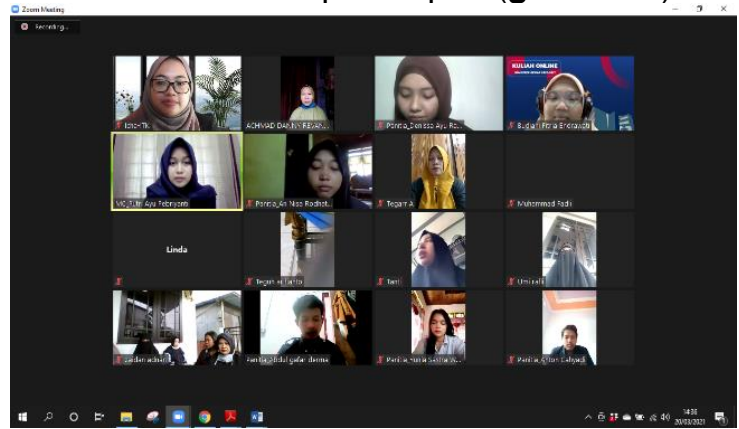

Gambar 1. Webinar yang telah dilaksanakan (Sumber : Penulis).

Webinar yang dilaksanakan bertujuan untuk mengenalkan potensi baru dari lele untuk dapat diolah menjadi kerupuk ikan lele. Sebelum webinar, dari 18 orang peserta hanya sebesar $5.6 \%$ saja yang membuat kerupuk ikan lele. Setelah webinar, angka ini meningkat menjadi $77.8 \%$ peserta yang membuat kerupuk ikan lele (gambar 2).

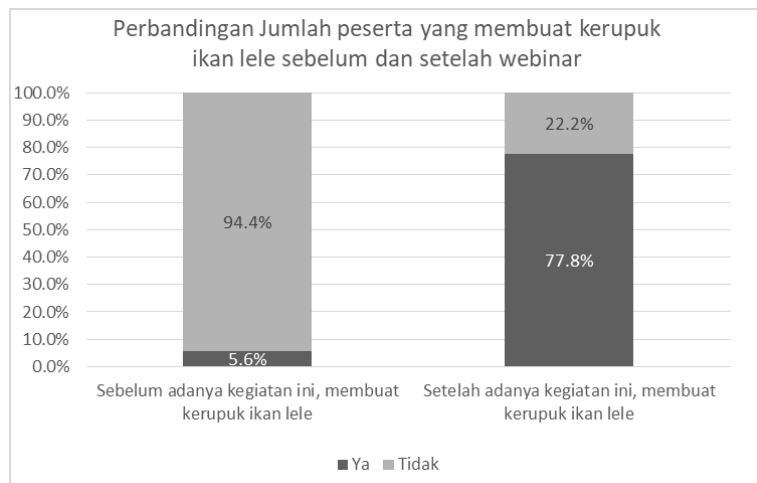

Gambar 2. Perbandingan jumlah peserta yang membuat kerupuk ikan lele sebelum dan setelah webinar (Sumber : Olahan Penulis).

Setelah kegiatan ini webinar selesai diadakan, kurang dari setengah peserta yang akan menjadikan ikan lele sebagai bisnis, yakni sebesar $44.4 \%$ saja (gambar 3). Beberapa faktor yang membuat peserta tidak ingin menjadikan kerupuk ikan lele ini sebagai bisnis adalah karena hasil dari pembuatan kerupuk yang masih kurang memuaskan, salah satunya 
yaitu kerupuk masih belum dapat mengembang dengan baik dan kerupuknya agak keras. Faktor lainnya adalah dari faktor pemasaran maupun teknik penjualan yang masih belum dikuasai. Beberapa juga terkendala dengan kondisi keluarga yang masih memiliki anak bayi, dan juga beberapa hanya ingin menambah ilmu saja sehingga belum berminat untuk menjadikan kerupuk ikan lele ini sebagai bisnis.

Apakah setelah adanya kegiatan ini, Anda akan menjadikan kerupuk ikan lele ini sebagai bisnis Anda?

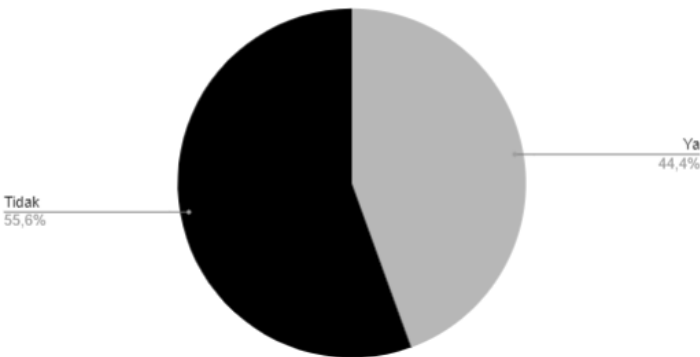

Gambar 3. Perbandingan peserta yang akan menjadikan kerupuk ikan lele sebagai bisnis dan tidak setelah kegiatan. (Sumber : Olahan Penulis).

Sementara itu, kegiatan ini dirasakan memberi kebermanfaatan. Hal ini dapat dilihat dari $94.4 \%$ peserta menyatakan bahwa kegiatan ini memberikan manfaat bagi anda (gambar 4)

Apakah kegiatan ini memberi manfaat bagi Anda?

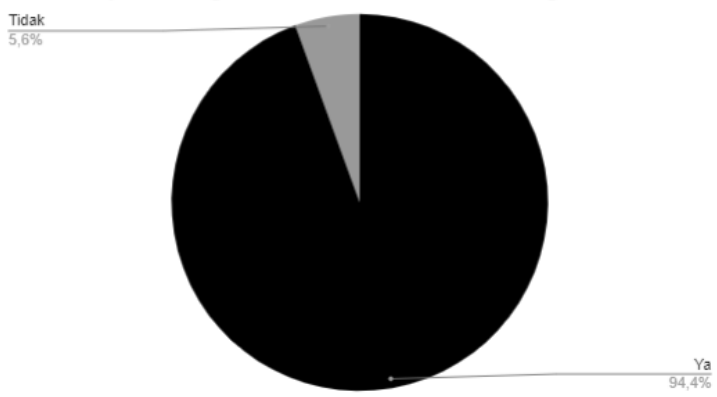

Gambar 4. Perbandingan peserta yang menyatakan bahwa kegiatan ini bermanfaat atau tidak. (Sumber : Olahan Penulis).

\section{Pembuatan dan Penjualan Kerupuk Ikan lele}

Selain melakukan pelatihan melalui webinar, tim pengabdian masyarakat juga mendampingi secara langsung pelatihan untuk membuat kerupuk ikan lele ini. Hal in dilakukan dengan hanya menghadirkan beberapa orang peserta dan hanya 2 anggota tim yang berangkat ke lokasi. Hal ini dilakukan untuk meminimalisir terjadinya kerumunan dan meminimalisir potensi penyebaran covid - 19 (gambar 5).

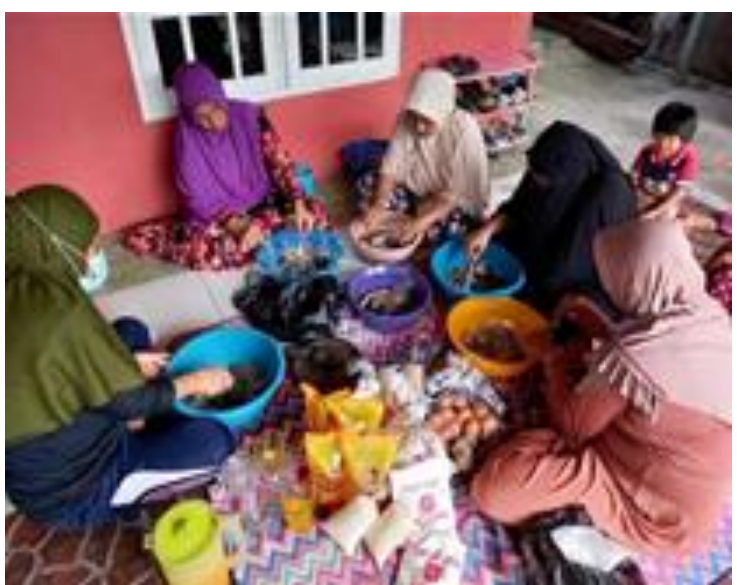

Gambar 5. Pendampingan pelatihan pembuatan kerupuk dari ikan lele (Sumber :

Penulis).

Setelah melakukan kegiatan webinar dan monitoring secara daring, promosi terhadap kerupuk ikan lele yang telah dibuat dilakukan untuk menarik pembeli/konsumen. Beberapa cara dilakukan untuk melakukan promosi antara lain mempromosikan kepada teman arisan, menjual di warung sendiri, atau menjual secara online via Whatsapp dan aplikasi e-commerce.

Berikut merupakan salah satu foto kemasan kerupuk yang telah jadi dan siap dipasarkan. Terdapat 2 jenis pengemasan kerupuk ikan lele, yaitu kemasan standing pouch (kemasan kecil dengan ukuran $10 \mathrm{~cm} x$ $17,6 \mathrm{~cm}$ ) dan kemasan besar dengan ukuran 14 $\mathrm{cm} \times 22 \mathrm{~cm}$ (gambar 6).

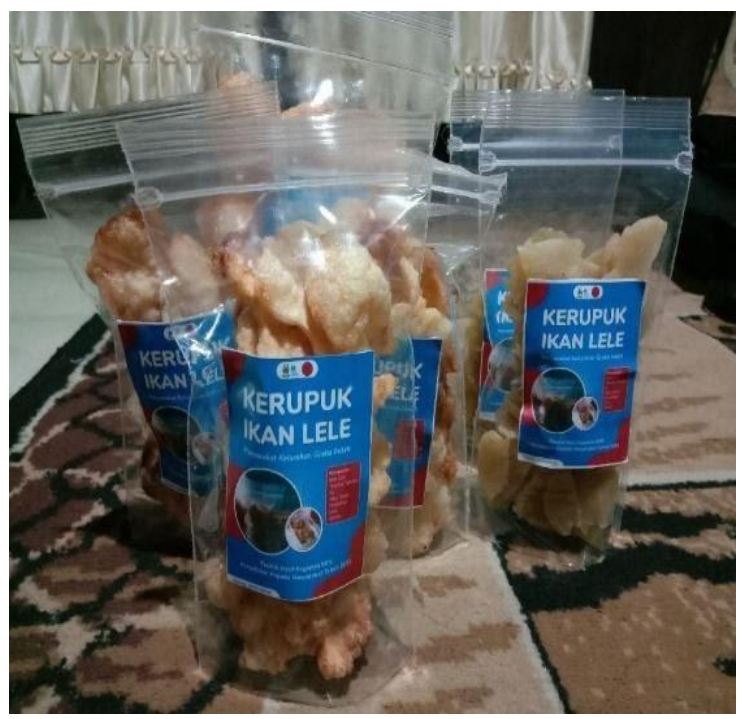

Gambar 6. Kemasan Kerupuk Ikan Lele Yang Dihasilkan oleh peserta. (Sumber : Penulis).

Hasil produksi kerupuk dalam kegiatan ini dengan total 49 kemasan, merupakan hasil gabungan antara RT 5 dan RT 60 . Untuk warga RT 5 yang ikut membuat sebanyak 9 orang dan 
menjualkan sebanyak 8 orang dengan total kemasan 43 kemasan yang terdiri dari 38 kemasan kecil dan 5 kemasan besar. Sedangkan untuk RT 60 yang ikut memproduksi kerupuk sekitar 10 orang dan menjualkan sebanyak 1 orang dengan total kemasan 5 kemasan yang terdiri dari 3 kemasan kecil dan 2 kemasan besar. Selain itu dari penjualan kerupuk yang laku sebanyak 44 kemasan dan tidak laku sebanyak 5 kemasan. Untuk meningkatkan penjualan ini, untuk langkah selanjutnya tim dapat juga melakukan perbaikan mutu proses dan peningkatan efisiensi usaha ditempuh dengan kegiatan in depth interview, diskusi dan brainstorming dan intervensi fisik, yang telah diteliti memiliki kebermanfaatan untuk meningkatkan penjualan pada penelitian terdahulu(Sudjadi et al., 2018).

\section{Kendala Pelaksanaan Kegiatan}

Program Mahasiswa Mengabdi Desa dilakukan di Kelurahan Graha Indah, Kecamatan Balikpapan Utara, tepatnya pada RT. 5 dan RT. 60 dekat Pemancingan Rama. Dikarenakan tingginya perkembangan kasus COVID-19 yang terjadi di Kelurahan Graha Indah, maka berdasarkan kesepakatan bersama antara Ketua RT. 5 dan RT. 60, diputuskan bahwa Program Mahasiswa Mengabdi Desa dilakukan secara daring untuk meminimalisir penularan virus COVID-19. Kegiatan ini terlaksana secara daring melalui zoom meeting untuk pemberian materi webinar sosialisasi pelatihan. Namun, bahan pembuatan kerupuk ikan lele diberikan secara langsung kepada peserta mitra (warga RT. 5 dan RT. 60). Pada saat pemberian bahan pembuatan kerupuk ikan lele, terjadi keterlambatan oleh peserta mitra dalam mengambil bahan. Hal ini dikarenakan adanya kesalahpahaman antara tim penanggung jawab (PJ) dengan warga, yaitu tidak adanya konfirmasi yang diberikan dari pihak warga kepada tim PJ pada saat pemberian bahan.

Selain itu, kendala yang dihadapi adalah minimnya response dari peserta mitra di grup Whatsapp sebelum pelaksanaan webinar, saat membahas tentang permasalahan teknis yang mungkin akan dihadapi selama pelaksanaan webinar. Sehingga pada saat webinar berlangsung, ada beberapa peserta mitra yang mengalami kendala saat bergabung ke zoom meeting. Akan tetapi, terlepas dari kendala yang ada, kegiatan webinar berjalan dengan lancar.

\section{Potensi Keberlanjutan}

Potensi keberlanjutan pada kegiatan ini adalah dari tim Program Mahasiswa Mengabdi Desa Kelompok 9 akan membuatkan buku pedoman UMKM yang akan membahas antara lain: resep pembuatan kerupuk ikan lele, baik dari segi pengolahan dan segi pemotongan kerupuk penjemuran kerupuk, teknik pengemasan, dan teknik penjualan secara offline maupun online. Diharapkan agar buku pedoman ini dapat membantu masyarakat untuk meneruskan Program Mahasiswa Mengabdi Desa yang memiliki tema Pemberdayaan Masyarakat Pemancingan Rama Melalui Pelatihan Pengolahan Kerupuk Ikan Lele Guna Meningkatkan Perekonomian Masyarakat Kelurahan Graha Indah. Saat ini, penulisan buku pedoman UMKM masih dalam tahap penulisan resep.

\section{SIMPULAN DAN SARAN Simpulan}

Dalam kegiatan yang bertema tentang UMKM di Kelurahan Graha Indah RT 05 dan RT 60 berjalan selama 5 bulan dalam satu semester dapat ditarik kesimpulan bahwa hasil produksi kerupuk dengan total 49 kemasan dari gabungan RT 5 dan RT 60. Untuk warga RT 5 yang ikut membuat sebanyak 9 orang dan menjualkan sebanyak 8 orang dengan total kemasan 43 kemasan yang terdiri dari 38 kemasan kecil dan 5 kemasan besar. Sedangkan untuk RT 60 yang ikut memproduksi kerupuk sekitar 10 orang dan menjualkan sebanyak 1 orang dengan total kemasan 5 kemasan yang terdiri dari 3 kemasan kecil dan 2 kemasan besar. Selain itu dari penjualan kerupuk yang laku sebanyak 44 kemasan dan tidak laku sebanyak 5 kemasan.

\section{Saran}

Adapun karena banyak peserta yang masih merasa belum berhasil dalam pembuatan kerupuk ikan lele yang layak jual, tim disarankan untuk mengembangkan resep kerupuk ikan lele yang lebih mutakhir untuk dimanfaatkan oleh peserta kegiatan.

\section{UCAPAN TERIMAKASIH}

Terima kasih tim tujukan untuk Lembaga Penelitian dan Pengabdian Masyarakat Institut Teknologi Kalimantan (LPPM ITK) yang telah mendanai kegiatan ini. Selain itu, tim juga mengucapkan terima kasih terhadap segenap warga dan perangkat RT 05 dan RT 06 Kelurahan Graha Indah yang sudah sangat aktif dalam mendukung bersama kegiatan ini agar berjalan dengan lancar.

\section{DAFTAR RUJUKAN}

Asriani, A., Santoso, J., \& Listyarini, S. (2019). Nilai Gizi Konsentrat Protein Ikan Lele Dumbo (Clarias Gariepenus) Ukuran Jumbo. Jurnal Kelautan Dan Perikanan 
Terapan (JKPT), 1(2), 77. https://doi.org/10.15578/jkpt.v1i2.7257

Bahtiar, R. A., \& Saragih, J. P. (2020). Dampak Covid-19 Terhadap Perlambatan. Kajian Singkat Terhadap Isu Aktual Dan Strategis, 12, 19-24.

Balikpapan, B. P. S. K. (2019). Kecamatan Balikpapan Utara Dalam Angka 2019.

Listyarini, S., Asriani, A., \& Santoso, J. (2018). KONSENTRAT PROTEIN IKAN LELE DUMBO (Clarias Gariepenus) AFKIR DALAM KERUPUK MELARAT UNTUK MENCAPAI SUSTAINABLE DEVELOPMENT GOALS. Jurnal Matematika Sains Dan Teknologi, 19(2), 106-113.

https://doi.org/10.33830/jmst.v19i2.113.2 018

Rosita, R. (2020). Pengaruh pandemi Covid-19 terhadap UMKM di Indonesia. Jurnal Lentera Bisnis, 9(2), 109-120.

Sudjadi, A., Jaryono, \& Sunarko, B. (2018). PERBAIKAN MUTU PROSES DAN PENINGKATAN EFISIENSI BISNIS PADA INDUSTRI KECIL KRUPUK LELE "ENDUL" DI DESA REJASARI, PURWOKERTO BARAT. Prosiding Seminar Nasional Dan Call for Papers "Pengembangan Sumber Daya Perdesaan Dan Kearifan Lokal Berkelanjutan VIII", 1-10. 